\title{
Students' Perception toward the Application of Kahoot! as an Assessment Tool in EFL Class
}

\author{
Nurhadianti, Bambang Widi Pratolo* \\ Master Program of English Language Education, Universitas Ahmad Dahlan, Indonesia
}

Received March 17, 2020; Revised April 15, 2020; Accepted April 27, 2020

Copyright $\odot 2020$ by authors, all rights reserved. Authors agree that this article remains permanently open access under the terms of the Creative Commons Attribution License 4.0 International License

\begin{abstract}
Teaching and learning environment in this $21^{\text {st }}$ century cannot be separated from the use of technology. This phenomenon, somehow, challenges the teachers even lecturers in creating their own teaching strategies combined with the use of technology. It is believed that, designing an assessment combined with technology in the form of fun activity like game can be much affordable to empower students' involvement, increase the classroom atmosphere and enhance the overall of students' learning experience. That is why this research is aimed to investigate students' perception toward the use of Kahoot! as an assessment tool. The study was conducted at a private university in Yogyakarta with four male and four female students of Magister Program of English Education chosen as participants. This research is a phenomenological qualitative research by applying a semi-structured interview to obtain information from the participants. The findings present that the inclusion of Kahoot! in teaching and learning process influenced the curiosity of students and increased their motivation and goals to be successful learners. The findings also showed that Kahoot! enhanced the quality of students' learning, with the biggest impact on the classroom atmosphere and also engagement and progress in learning activity. Besides, this assessment tool offers a convenient feedback to help students in improving their motivation in learning. Thus, Kahoot! can be utilized effectively in assessing students' mastery on the subjects offered.
\end{abstract}

Keywords Education 4.0, Assessment, Perception, Kahoot!

\section{Introduction}

Nowadays, the uses of information, internet, and technology cannot be avoided to support the teaching and learning process. The use of digital technology for academic functions all together with second and foreign language acquisition is increasing speedily [1]. Therefore, this is really important to apply the core of revolution 4.0 in the educational system to connect with the globalization era [2]. According to Hussin [3] education 4.0 in the $21^{\text {st }}$ century is all about the implementation of digital technology. In higher education in Indonesia, the advancement of technologies keeps on changing and transforming the teaching method and the setting of the learning process. In educational system, there have been many lecturers even teachers using some internet media to post students' grades and assignments via online [4]. Moreover, students are required to use internet applications such as social media to complete their tasks and sharing some ideas about their assignment. Besides, this also helps the lecturer directly send an assignment in the group of social media that they frequently used. The lecturer will no longer use the traditional method like writing on the board to assign the students.

Furthermore, by the development of technology, lecturer can directly provide assessments for students after the lecture session is over. Assessment is a judgment concerning the performance of learners who supported specific weighted set goals [5]. According to Brown [6] there are two types of assessment, namely summative and formative assessment. A type of assessment that aims to measure or summarize what a student has grasped and typically occurs after a course or unit instruction is described as a summative assessment. While an assessment which has feedback during the course of teaching is termed formative assessment. This assessment additionally mentioned as evaluation for learning that is progressively emphasized within the educational system. In conducting the assessment, many students usually feel nervous and anxious, and the class atmosphere tends to be more strain and silent. In terms of assessment, Kahoot! was considered a connective approach for lecturers to check students' learning acquisition after each lesson [7]. Receiving immediate feedback and responses from the instructor is 
one of the features in Kahoot. Direct feedback and result from Kahoot! helped the teachers to create effective time assessments to the students at the same time.

The influence of Education 4.0 has changed the classroom atmosphere in doing an assessment. Schunk, Meece, and Pintrich [8] defined a classroom atmosphere that is usually equated with classroom climate or classroom environment that refers to the social, psychological, and emotional options of the atmosphere or environment of the classroom. According to Dellos [9], Kahoot! may be a student response system that persuades students through the game. Not only game, Siegle [10] explained that this tool requires quizzes which contain questions that have up to four options, and this may contain varied multimedia system contents like photos or videos. Kahoot! is a web international academic platform which enables students to give a free response [11]. It is freely accessible and a game-based learning platform that has attained large response broadly with over thirty million users worldwide [12]. Applying Kahoot! in language learning is an excellent choice that teachers can use to create quizzes to assess students' achievement by adopting multiple-choice questions served in a game-based design for students [13]. It also emphasizes learning styles that involve the active role of participation of learners with their peers in a competitive manner through the learning process. In other words, Kahoot! can influence a child's emotional social development in the ability to compete and collaborate [14].

The advantages of Kahoot!, among others, for examples: this web tool allows teachers to make quizzes, discussions, and surveys by including various elements such as video, images, and text [15]. The students can access it easily by using a variety of different devices such as smartphones, tablets, laptops and other devices easily. Furthermore, there have been an increasing number of studies focusing on applying Kahoot! in language learning e.g. [7]; [15]; [16]. The result of those studies succeeds in gaining students' behavior in improving their knowledge. However, those studies only focus on examining the use of Kahoot! in improving a specific skill. In fact, Kahoot! can also be used as an assessment tool. This has been proven by Al-Manar's study in 2019 which focused on using Kahoot! as an assessment tool for measuring vocabulary mastery [7]. However, Al-Manar's research needs to be equipped in order to support and prove that Kahoot! which can be useful for both teachers and students in the assessment session. Thus, this research is intended to provide more evidence by utilizing interview instruments in collecting data. The researcher believed that examining the interpretation of those people who have experience in using Kahoot! will give more accurate evidence to support the previous findings. So, the use of Kahoot! will give no doubt anymore. In addition, this research aims to measure the influence of technology in adapting the revolution of education 4.0. The research questions for this research can be stated as follows: 1) How does the influence Kahoot! in the classroom atmosphere? 2) How does the application of Kahoot! influence students' engagement? 3) How does the application of Kahoot! influence students' motivation? 4) How does the application of Kahoot! enrich learning experiences?

\section{Methods}

This research is designed under phenomenological qualitative research. Husserl [17] stated that this approach focuses on understanding phenomenon which is based on particular group experience perspective. It is an approach in qualitative research that investigates the similarity of people's life experience [18]. A purposive sampling was used to choose the participants. It is a technique to establish the sample by any considerations [19]. Therefore, the sample was chosen deliberated based on the specific criteria decided by the researcher. Here some criteria of the sample in this research: 1) the student in English language program, 2) the student who joins the IC Class of Language Testing course, and 3) the student who have played Kahoot! more than five times. Based on these criteria, eight students consisting of four females and four males were chosen as the participants of this study. Their ages ranged between 23 and 28 years old.

Meanwhile, a semi-structured interview conducted in a conversational style [20] was used as the instrument of the study. The instrument was proposed to figure out students' perceptions relating to the utilization of Kahoot! within the setting of their engagement, motivation, and learning. Besides, it is a good way to discover learners' motivation behind their choices and behavior toward Industrial Revolution 4.0 [21]. The researcher collected the data through interview with respondents who had experienced in using Kahoot! as an assessment tool or quiz for more than 3 months in Language Testing class. The researcher prepared a set of questions as a guidance in conducting interviews. The interview process was conducted in an informal conversational style so that researchers could collect accurately the data about their perception of using Kahoot! as an assessment tool. This technique was used in order to help the researcher to develop a keen understanding on the topic that was necessary for developing relevant and meaningful semi-structured questions. Voice recorders were also used when conducting interviews; this aimed to avoid the loss of important information conveyed by the participants. The researcher extracted the results of the recording in writing form in Microsoft word. In analyzing the data, the researcher began by arranging a set of descriptive comments on the interview transcript. A descriptive comment was used to establish the data collection. There were some underlying cores such as descriptions, explanations, and emotional responses that could be revealed by the researcher in descriptive comments. 


\section{Findings}

Based on data analysis, the researcher highlighted seven key conditions that indicate students' perception toward the use of Kahoot! as assessment tools: 1) attracting students' focus and attention 2) new learning styles' 3) interactive learning 4) facilitate learning 5) effective and instant feedback 6) increasing and retaining knowledge 7) fun and enjoyment. The participants' names were not included but they were only abbreviations, such as FS1 (the female student 1), MS2 (the male student 2), and so on. The researcher examines the result for each of the seven key categories within the following subsections.

Attracting Students' Focus and Attention. The data showed that 7 of 8 participants highlighted the use of Kahoot! as enabling them to more focus and keep their attention on learning activity. They said that they pushed themselves to keep focus not only in Kahoot! session but also after the session.

"I need to keep my attention to the topic being delivered by the presenter to know what the answer is in Kahoot! later. Actually, it is kind of a good way to push the students' attention to learning." (FS 4)

"If you want to succeed in completing the questions in the Kahoot! session, the important things that should be done is keeping our concentration and focus on the material being conveyed." (MS 3)

The students mentioned that the use of Kahoot! as a learning evaluation tool was a better option. It motivated them to give their focus and attention amid the learning activity. Moreover, it can persuade them to tightly deal with the subject being presented in arranging the plan for a quiz to reply to the questions accurately.

New Learning Styles. The participants assumed Kahoot! as a unique way to do an assessment. They mentioned that learning with Kahoot! could create a fascinating learning style compared to traditional assessment styles; like doing an assignment by handwriting summarizes of the topic being presented.

"The most interesting one that I like from using Kahoot! was it's really push students to adapt with education 4.0, new learning style, new assessing style, help us to simplify the teaching and learning process." (MS 4)

"Kahoot! is a new style of assessment, for a teacher, Kahoot! really helps us to minimize our time in correcting students' assignment" (MS 3)

Kahoot! as an assessment tool can help students and teachers do the assessment. It helps students not to feel bored and nervous about working on quizzes, while the teachers can safe their time. The teachers did not need to check one by one the quiz result that has been done by students; the teacher simply looks at the final resume in the Kahoot! application.

Interactive Learning. Using Kahoot! offers students more possibilities to mingle or interact with their lecturer and classmates. They stated that Kahoot! make them more associated with their friends as well as with the lecturer, either during the class or after the learning session.

"Kahoot! session made our classrooms become more interactive. We tend to did more discussions after all those questions being answering in order to reveal the appropriate answer or to expand our understanding about the topic in that question." (FS 3)

"We mostly did an effective discussion after the Kahoot! session, we usually compare our opinion and ideas with our friends. In the end, this helped us understand deeply about the topic being explained, tested using Kahoot!, and last discussed more clearly." (MS 1)

The application of Kahoot! as an assessment tool provides a great influence on the students' learning experience. Correspondingly, it is supported by Plump and LaRosa [12] that found most of participant in their research are engaged with Kahoot!. The students noticed Kahoot! has created their learning a lot of pleasant, present in simple way, interactive and serving to the student to more comprehend their subjects. It can be concluded that Kahoot! can stimulate student participation to engage in learning activities.

Facilitating Learning. Almost all of the participants agreed that Kahoot! is a valuable education tool. They really appraise Kahoot! that can give a positive impact on their learning involvement. Six of the eight participants declared that participating in Kahoot! session might encourage them to keep in mind with the covered material so that they could complete the questions in Kahoot! session. Then, five participants notified that Kahoot! could increase their knowledge during the learning session.

"You have to really listen to the explanation in order to answer correctly the questions in Kahoot!." (MS 1)

"Kahoot! motivated me to absorb all the material presented, not only to answer Kahoot! but more than that it was a learning process for me, and Kahoot! was very helpful." (FS 4)

Based on the result above, we can see that students take pleasure of Kahoot! since it was connecting to the course by revolved advanced ideas and encouraging knowledge into applications of theory. The main function that students mentioned were, however, Kahoot! assisted revision and helped them to retain knowledge [22].

Effective and Instant Feedback. All participants stated that Kahoot! was truly impacting their learning. The post-Kahoot! session provides them to review the material, point out the different conclusions and facilitates them to assess their cognition as compared with their peers. This application gives them feedback right away after the quizzes finished. They can directly recognize whether their answers are true or false right after answering the question the question.

"I can directly know that my answer is wrong, I usually make a note to review which parts I did not understand 


\section{about the topic on that day." (MS 4)}

Besides, Kahoot! can attract students' curiosity when their answer is wrong. They will explore the answers and try to understand why they were wrong. Kahoot! really helped students to generate a deeper understanding that strongly supports students' engagement and retention of knowledge.

Increasing and Retaining Knowledge. The majority of the participants confessed that Kahoot! is a faster and easier e-learning platform that can stimulate their memory to keep interacts with the topic.

Kahoot! was really helping me in correcting my understanding of the subject material being discussed, like when I got my answer was wrong, it will make me easier to remember that mistake. Then in the future that mistaken won't happen anymore." (FS 3)

It can be said that Kahoot! helped students to comprehend more and retain the main focus during the lecture session, and also gave an update about what is being discussed. In addition, Kahoot! increased students' knowledge; they tend to remember more when new information was introduced through a Kahoot!.

Fun and Enjoyment. Based on the data collection, it showed that all participants enjoyed in using Kahoot! as an assessment tool. Kahoot! was claimedto create an energetic and fun class, this tool becomes an icebreaker for students. Kahoot! can also be viewed as a competition moment for students that will improve the classroom atmosphere. Ismail and Mohammad[23] proved that Kahoot! leads to students' engagement. The pleasant classroom atmosphere greatly helped students to learn, it motivates them to just accept the challenges, be competitive, and stimulate their learning.

"It was really enjoyable in Kahoot! session, it is not a stressed assessment, I answered questions in a relax way." (FS 1)

"It is interesting Kahoot! pushes me to do my best, I always try to reach the top three positions. Kahoot! was really exciting session." (FS 2)

Interestingly, almost all participants gave positive answers toward their perception of using Kahoot!. They strongly agreed that using Kahoot! as an assessment tool is fun. They perceived Kahoot! as an element that can push them in enhancing the learning activity, contributing to retaining their knowledge and engagement in the learning process. Therefore, the researcher elaborates the data gathering in order to answer the research question as stated at the beginning.

\section{Discussion}

Kahoot! gave students a lot of opportunities to have interaction with their friends, lecturer, and the learning materials. It can be seen from participants' respond in answering the questions above. Most of them perceived that Kahoot! helped them in creating a new experience of learning which is represented as fun learning activity supported to a pleasant classroom atmosphere. This is really different learning experience compared to a conventional style that. This finding strengthens a study by Dellos [9] in promoting the use of Kahoot!, as safe, competitive, engaging and fun. Kahoot! is valuable not only for academic purposes but also for psychological purposes. The students show the curiosity when they are focused on the learning content and defend their attention throughout course. The researcher observed that the desire of the participants to increase their knowledge can be seen from their effort to keep concentrated to the course. Kahoot! was approved as a great tool to promote classroom interaction during and after the Kahoot! session, which strongly influences students' ability to remember the content which has been learned. Furthermore, Kahoot! can increase the interaction between students and lecturer; students and peers. It also influenced students' motivation to perform well in order to be better than their peers. In conclusion, Kahoot! makes the classroom atmosphere become more excited and fun.

Students believe that Kahoot! attracted their attention, mind, and interest throughout the course. Refer to the findings, it conveys that in a context of examining their answers whether that was correct or incorrect, the students attempt to understand and investigate why they were right or wrong. Based on this condition the students were able to establish a deeper understanding that strongly supports their ability to remember and engage in learning activity. These findings also support the previous research by Siegle [10] who stated that engagement can increases students' interactions with content, lecturer, and peers as well as enhances their creativity in many instances. Another notable outcome, researcher found that there is a shred of evidence that a depth understanding of the students was obtained from the results of the discussion after Kahoot! session has finished. After playing Kahoot! in a prominent condition, from the students' standpoint, it refers to the circumstances that authorize the students with lecturer doing discussion in a more enthusiastic situation and with the possibility for getting immediate feedback [22].

The findings have proven that students were considerably motivated by Kahoot! in the learning process. In addition, Kahoot! also promotes interaction between students and lecturers; students and peers within the classroom. Students were motivated to be concentrating on what is being discussed or presented if they wanted to get a good score in the Kahoot! session latter. It also motivated students to be more competitive within the course, where students were pushed by their own desire to see their names arise as the best scorer of the scoreboard. In accordance with this, Ismail and Mohammad [23] stated that Kahoot! may motivate students to encounter challenges and capable 
to manage it, retain and encourage their interest in the learning process as well as worth the Kahoot! session as a helpful action for learning. Competition is commonly used as a tool within the classroom to extend students' motivation in learning. It was proven by the information obtained from the participants who admit that Kahoot! can stimulate their ambition to be competitive. However, Reeve and Deci in [24] stated that the competition may have consequents within the classroom. They assumed that competition will decrease overall performance, cooperation, and problem-solving, and additionally has a positive relationship with cheating. Therefore, the researcher used Kahoot! in the learning process which means to enhance students' attention and motivation, and also propose a healthy competition during classroom activity.

The participants agreed that using Kahoot! in learning process had a trustworthy influence on increasing knowledge, competence and ability. They stated that Kahoot! directs students to extend their attention and interaction within the classroom. In the study of Bicen and Kocakoyun [25], Kahoot! is really appropriate for teaching and learning activities. Kahoot! helps learners to develop cognitive skills like thinking and problem-solving. Moreover, it facilitates students to focus on significant subject matter that was delivered in classroom. In addition, the application of Kahoot! is not only increasing the learning atmosphere but also enhancing the information retention over the course [26].

\section{Conclusions and Suggestion}

The expanding and development of technology has led the learning environment into competitive formation. That is why the researcher thinks that this study will be very important and beneficial to be conducted, not only as a research study but also as the information that will open our mind on Kahoot!. People will now know that Kahoot! is not only an application for fun but also an application which will help many teachers and students in improving the learning atmosphere. The data indicate that the use of Kahoot! in learning heightens student interest in the lesson and encourages them to become more ambitious for success. The use of Kahoot! in higher education has proven that this tool may be motivating and extremely helpful for the learning assessment. Kahoot! as assessment tools will lead students to become a lot of concerned and suppose more deeply concerning the topic underneath study and facilitate the constructing of knowledge and consideration on the portion of the students. This research suggests that the application of Kahoot! promotes larger student engagement in learning and fosters educational success. The results found, and in particular the fact that the students think about what they'd wish to continue using this application.

\section{REFERENCES}

[1] B.W. Pratolo and H.A. Solikhati, "The implementation of digital literacy in Indonesian suburban EFL classes," International Journal of Scientific and Technology Research, 9(1), 1508-1512, 2020

[2] C. W. Anggraeni, "Promoting Education 4.0 in English for Survival Class: What are the Challenges?" Metathesis J. English Lang. Lit. Teach., vol. 2, no. 1, p. 12, 2018.

[3] A. Aziz Hussin, "Education 4.0 Made Simple: Ideas For Teaching,” Int. J. Educ. Lit. Stud., vol. 6, no. 3, p. 92, 2018.

[4] H. Halimah, G. A. Ibrahim, and N. Lustyantie, "Cello As a Language Teaching Method in Industrial Revolution 4.0 Era," English Rev. J. English Educ., vol. 7, no. 1, p. 75, 2018.

[5] M. Tara, "Assessment - Summative and Formative- some Theoretical Reflections," Br. J. Educ. Stud., vol. 53, no. 4, pp. 466-478, 2005.

[6] H. D. Brown, Language Assessment : Principles Classroom Practices. New York: Pearson Education, Inc., 2004.

[7] M. A. Al-Manar, "Reviewing Students' Vocabulary Mastery by Using Kahoot at Holmesglen Partnering With University of Muhammadiyah Tangerang," J. Teach. Educ., vol. 1, no. 2, pp. 88-99, 2019.

[8] D. H. Schunk, J. R. Meece, and P. R. Pintrich., Motivation in Education: Theory, Research, and Applications. New York: Pearson Education, Inc., 2012.

[9] R. Dellos, "Kahoot! A Digital Game Resource for Learning," Int. J. Instr. Technol. Distance Learn., vol. 12, no. 4, pp. 49$52,2015$.

[10] D. Siegle, "Technology: Learning Can Be Fun and Games," Gift. Child Today, vol. 38, no. 3, pp. 192-197, 2015.

[11] R. Byrne, "Kahoot - Create Quizzes and Surveys Your Students Can Answer on Any Device," 2013. [Online]. Available: https://bit.ly/2KjzYFZ. [Accessed:05-Nov-2019 ].

[12] C. M. Plump and J. LaRosa, "Using Kahoot! in the Classroom to Create Engagement and Active Learning: A Game-Based Technology Solution for eLearning Novices," Manag. Teach. Rev., vol. 2, no. 2, pp. 151-158, 2017.

[13] C. K. Dewi, "Pengembangan Alat Evaluasi Menggunakan Aplikasi Kahoot Pada Pembelajaran Matematika Kelas X," Universitas Islam Negeri Raden Intan Lampung, 2018.

[14] F. Rofiyarti and A. Y. Sari, "TIK Untuk Anak Usia Dini Penggunaan Platform Kahoot dalam Menumbuhkan Jiwa Kompetitif dan Kolaboratif Anak," J. Anak Usia Dini dan Pendidik. Anak Usia Dini, vol. 3, no. 3, pp. 164-172, 2017.

[15] M. Mansur and D. Fadhilawati, "Applying Kahoot to Improve the Senior High School Students 'Vocabulary Achievement," Voices English Lang. Educ. Soc., vol. 3, no. 2, pp. 164-173, 2019.

[16] J. Pede and A. Accardo, "The Effects of the Online Game 
Kahoot on Science Vocabulary Acquisition," Rowan University, 2017.

[17] E. Husserl, Phenomenology and the Foundations of the Science. The Hague, Netherlands: Martibus Nijhoff Publishers, 1980.

[18] M. Clark E, Phenomenological research methods. California: SAGE Publications, Inc., 1994.

[19] Sugiyono, Metode Penelitian Kuantitatif, Kualitatif dan Kombinasi (Mixed Methods), First Edit. Bandung: Alfabetha, 2015.

[20] M. Didik, Nuridin, and Mubarok, "The Undergraduate Student' Perception toward the Edu-Techno Empowerment in the Class: Voice from Indonesia," Semarang, 2018.

[21] K. Raworth and S. Caroline, Conducting Semi-Structured Interviews. United Kingdom: Oxfam GB, 2012.

[22] M. Correia and R. Santos, "Game-based learning: The Use of Kahoot in Teacher Education," Int. Symp. Comput. Educ. SIIE 2017, pp. 1-4, 2017.

[23] M. A.-A. Ismail and J. A.-M. Mohammad, "Kahoot: A Promising Tool for Formative Assessment in Medical Education,” Educ. Med. J., vol. 9, no. 2, pp. 19-26, 2017.

[24] M. D. Hanus and J. Fox, "Assessing the Effects of Gamification in the Classroom: A Longitudinal Study on Intrinsic Motivation, Social Comparison, Satisfaction, Effort, and Academic Performance," Comput. Educ., vol. 80, pp. 152-161, 2015.

[25] H. Bicen and S. Kocakoyun, "Perceptions of Students for Gamification Approach: Kahoot as A Case Study," Int. J. Emerg. Technol. Learn., vol. 13, no. 2, pp. 72-93, 2018.

[26] S. A. Licorish, H. E. Owen, B. Daniel, and J. L. George, "Students' Perception of Kahoot!'s Influence on Teaching and Learning," Res. Pract. Technol. Enhanc. Learn., vol. 13, no. $1,2018$. 